\title{
Protection of the slab-column structures against progressive collapse
}

\author{
Barbara Wieczorek ${ }^{1, *}$ \\ ${ }^{1}$ Silesian University of Technology, Faculty of Civil Engineering, Gliwice, Poland
}

\begin{abstract}
The paper presents the problem of protection of reinforced concrete slab-column structures against the occurrence of a progressive collapse caused by punching in the support zone. The experimental studies and effects of recorded collapses indicate the necessity to use the appropriate reinforcement type, which will significantly increase the load capacity of the slab-column connection after punching. One of the ways to protect the structure is to use an integrity reinforcement as the most optimal method of strengthening. The contents explain the reasons for the application and description of issues related to this type of reinforcement. The conclusions from the use of this reinforcement based on the results of laboratory tests were presented.
\end{abstract}

\section{Introduction}

Over the last fifty years, many building failures and collapses of slab-column structures have occurred. Those incidents were predominantly caused by brittle fracture of concrete occurring locally at the column following the shearing or bending of a slab [22]. The imminent failure condition of the support zone preceding the punching was practically indiscernible. Hence, punching-induced building collapses led to the loss of lives and health impairment of many people, as well as to significant property damages [3] [4] [5]. For this reason, additional effective protection should be planned already at the design stage, enabling the avoidance or at least limitation of disastrous consequences in emergency situations. The list of building collapses of slab-column structures can be found in [21]. Sample post-failure images of selected buildings are presented in Fig. 1. Post-collapse research and building expertises have proven that the main reasons of failures were faults made both at the design stage and during the construction. As proven by the data [21], the majority of failures covered areas much larger than the surrounding of one slab-column connection, leading to partial or total building collapse [2] [3] [4] [5]. For this reason, the possibility of such situations should be prevented.

\footnotetext{
*Corresponding author: barbara.wieczorek.box@gmail.com
} 
1978, Switzerland, Morbio Inferiore, Serfontana shopping center

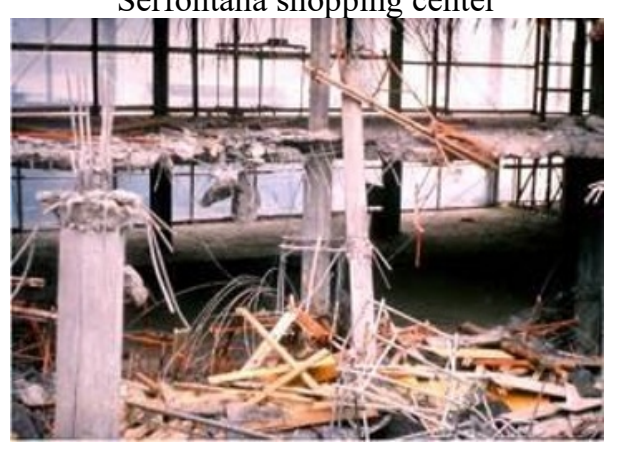

1981, USA, Florida, Harbour Cay Condominium

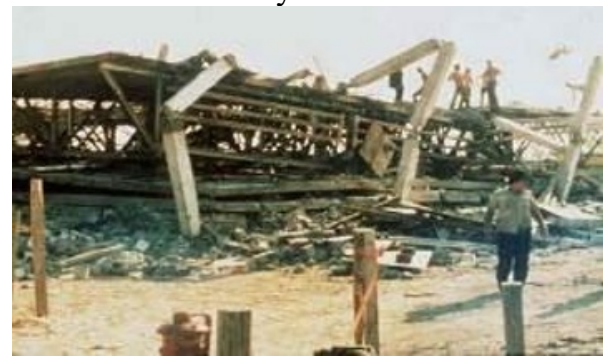

1997, Great Britain, Wolverhampton,

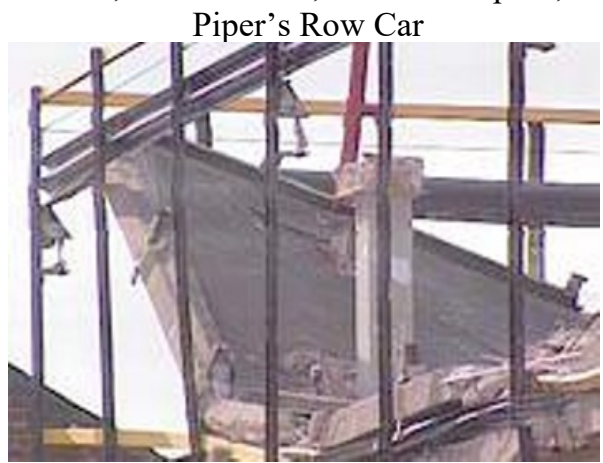

1955, USA, New York, Coliseum

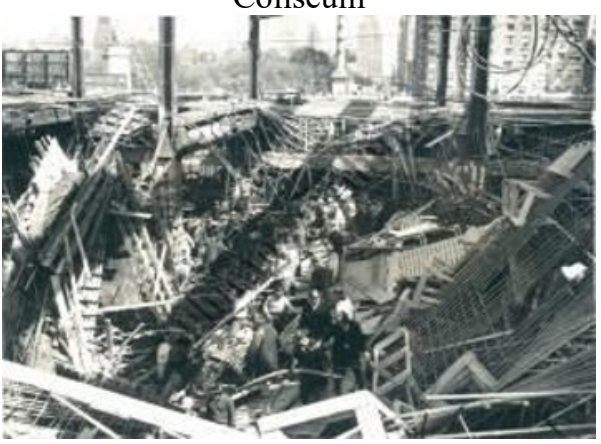

2008, Canada, Montreal, multi-level garage

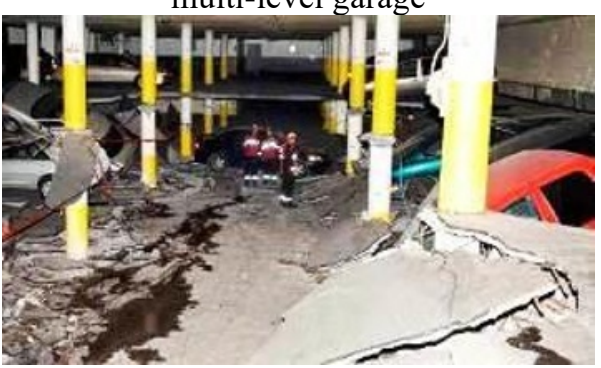

2003, USA, Atlantic City, Tropicana Casino parking garage

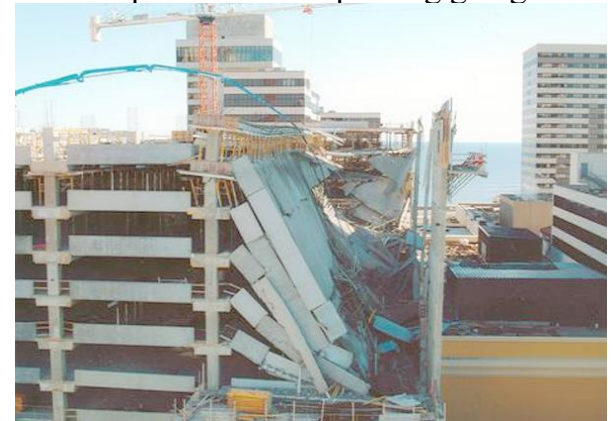

Fig. 1. Photos of selected failures of slab-column structures based on websites.

\section{Failure mechanism}

Reference works include a number of research papers regarding the protection of slab concrete structures against progressive collapse. They present various concepts of counteracting the possible effects of local failures. Among them, particular attention should be paid to the concept of inducing tensile membrane action as a useful mechanism for increasing the load-transfer capacity of structural elements. Based on this, already back in the last century, the concept of integrity reinforcement was put forward as the most recommended practical solution ensuring the increase of the load-bearing capacity of a slab-column connection after punching. 
Two situations in which a reinforced concrete slab-column connection can reach its load-bearing capacity and collapse should be considered as a starting point in analyzing the post-punching behaviour of slab column connections. Research referred to in papers [2] [17] [18] has proven that failures occurred as a result of shearing or bending in the support zone. In each of these cases, the collapse occurred at the moment when slab-column integrity was lost.

Research [1] (according to [22]) points at a significant difference between slab-column connections destroyed by shearing (A-type connection) and bending (B-type connection). Fig. 2 presents the change in the column displacement with regard to the slab in those connections under the rising load. If the shear capacity $V_{\text {shear }}$ was lower than the bending capacity $V_{\text {flex }}$, brittle shearing failure of the connection occurred. Conversely, when $V_{\text {shear }}$ exceeded $V_{\text {flex }}$, the stiffness of the support zone decreased as a result of the scratch spreading. The results suggested that the failure mechanism, and thus the limit load-bearing capacity of the connection $V_{\mathrm{u}}$, depended on the geometrical dimensions of the connection and the parameters of the reinforcement used. Additionally, it was observed that the displacement of the column at the moment of failure was higher in B-type than in A-type connection. Notwithstanding the initiating factor of the slab-column connection, its load-bearing capacity was lost.

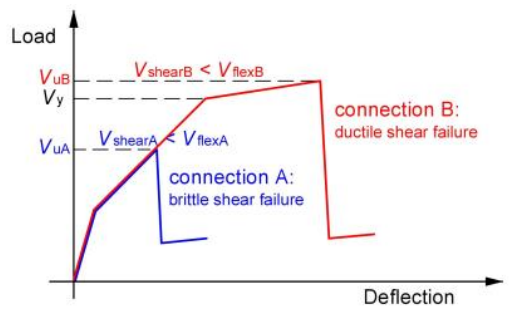

Fig. 2. Behavior of slab-column connections under conditions of the loss of shearing and bending capacity [1].

Depending on the proportions of the active moment and the lateral force, different scopes of damages in the support and span zones are obtained:

- local damage (Fig. 3a) where the floor damage does not exceed the scope of three times the thickness of the slab - only punching occurs,

- general damage of the significant part of the floor adjacent to the connection (Fig. 3b), where punching of the support zone is accompanied by an effort of the span zone,

- general damage of a large part of the floor adjacent to the connection (Fig. 3c), where a significant effort of the span zone occurs without punching - most commonly when the support zone includes shearing reinforcement.

Regardless of the final failure mechanism and notwithstanding the failure location, the damaged elements of the floor slab may finally hang on the columns, only if bottom reinforcement in the form of continuous bars was used [15]. In such a case, the structural arrangement presented in Fig. 3 may transform into a tendon structure where the load is taken over by axial tensioning forces resulting from a substantial deformation of individual structure elements [16]. Additionally, it should be stressed that punching-induced failure at one column can cause the forces to be redistributed and the load to be taken over by adjacent columns [20] [21]. 
a)

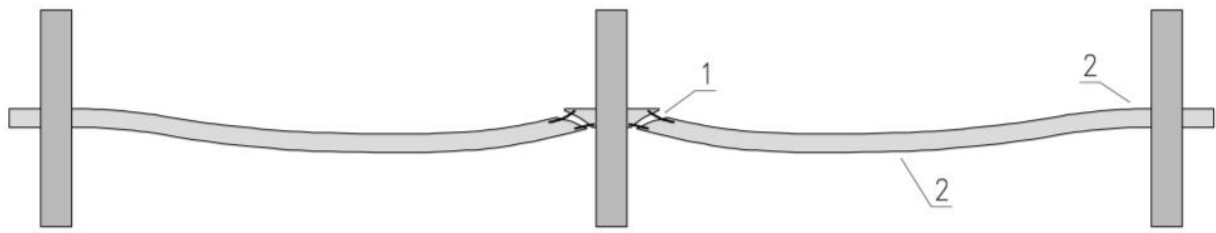

b)

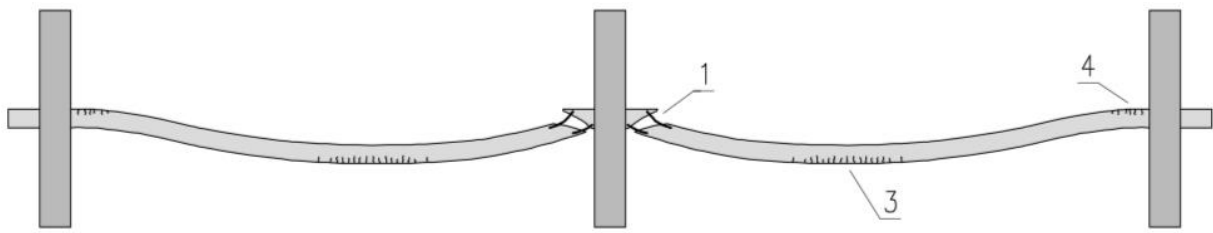

c)

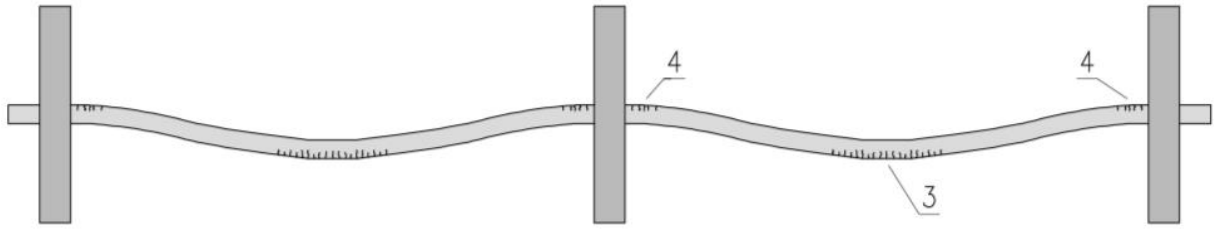

Fig. 3. Post-failure load-carrying mechanisms in concrete structures - tensile membrane action in reinforced concrete slabs after punching (described in the text): 1- area of punching, 2- lack of visible scratches, 3- many scratches of span area, 4- many scratches of support area.

According to the research [8], after punching in slab-column connections with continuous and discontinuous bottom reinforcement over the column, substantial differences in the failure mechanism occurred (Fig. 4). In connections including upper and bottom discontinuous reinforcement, after the punching failure the upper reinforcement bars were ripped off from the top surface of the slab, leading to a total loss of the column load-bearing capacity in the zone (Fig. 4a). Using additional, properly designed bottom reinforcement bars enabled the transfer of transverse forces onto the column (Fig. 4b). The presence of a continuous bottom reinforcement prevented the further spread of damages and could in consequence counteract the progressive collapse.

a)
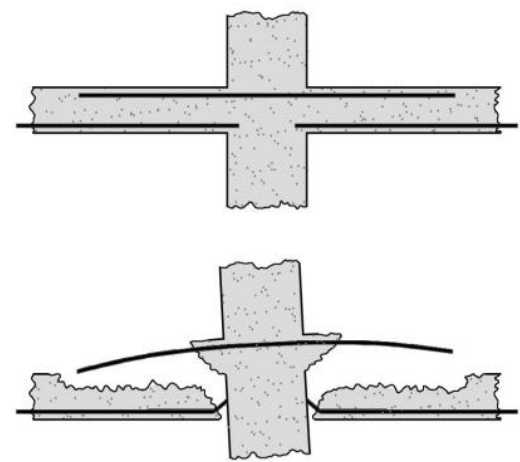

b)
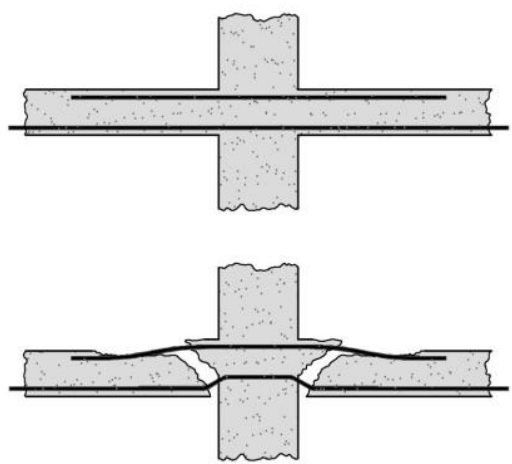

Fig. 4. Development of tensile membrane action in the case of monolithic, bi-directionally flexing plates: a) flat plate construction, b) internal field, c) edge field [8] [21].

The general behavior of a piece of a flat floor slab in a typical slab-column structure is presented in Fig. 5 according to recommendations included in [24]. 


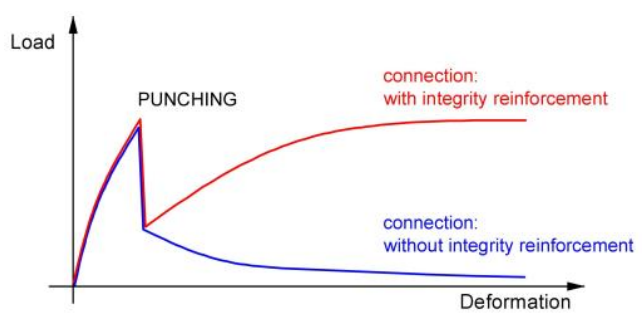

Fig. 5. Load-bearing capacity of the connection following the punching of a flat slab without and with integrity reinforcement [24].

\section{The impact of integrity reinforcement on securing the slab- column structure}

Based on the papers cited above, it can be concluded that only the longitudinal bottom reinforcement bars are able to play a significant role in transferring loads after the slab punching and ensure the connection between the punching cone and the remaining part of the slab.

After punching and with substantial deformations, the impact of other factors, such as the effect of dowel action and the impact of the compressed zone of concrete on the load-bearing capacity of the connection turned out to be minor [10] (according to [22]). Fig. 6 presents the possible behavior of upper reinforcement when slab-column connection with bottom integrity reinforcement becomes destroyed by punching. In the emergency state of the connection, the entire load will be transferred by the bottom longitudinal reinforcement. The integrity reinforcement bars will be deformed, and then will ensure the suspension of the slab on the columns as a result of tensile membrane action. The upper support reinforcement designed with regard to bending may potentially increase the load-bearing capacity after slab punching provided that proper anchoring is present (Fig. 6a). If the upper reinforcement has not its continuity properly maintained or is not properly anchored (Fig. 6b), the cover may start to spall, substantially or entirely reducing the extra load-bearing capacity. As the author's own research has proven, anchoring of the upper reinforcement as shown in Fig. 6 was not sufficient. Despite the double bending of bars, if concrete structure was substantially degraded, they were ripped out (Fig. 7).

Similar was the situation when bottom reinforcement bars were overlapping. In such a case, under the impact of substantial deformations, the integrity reinforcement may be ripped out, resulting in spalling of the cover of the slab bottom surface. As a consequence, integrity reinforcement bars will stop acting and fulfilling their function. Based on the research, it has been concluded that integrity reinforcement (particularly if reinforcing bars have larger diameters) should be longer than $2 l_{\mathrm{d}}$ recommended in CSA A23.3 [25] and ACI 352.1R [23] or its continuity should be maintained by means of welding of mechanical connectors (Fig. 8).

a)

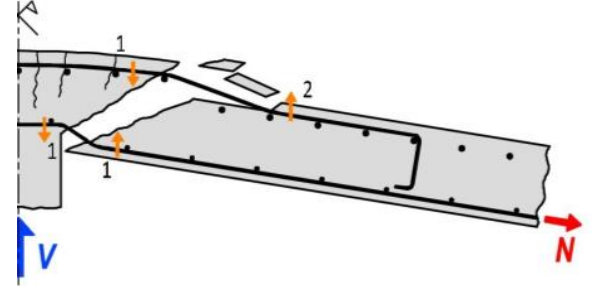

b)

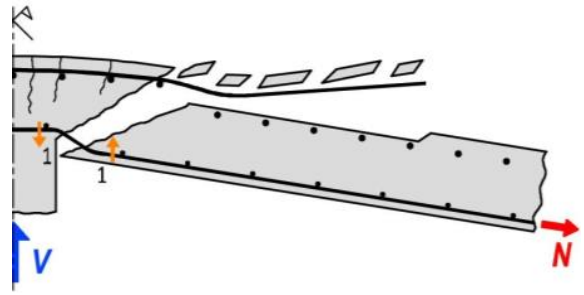

Fig. 6. Mechanism of transferring of shear forces through longitudinal reinforcement [74]: a) properly anchored top reinforcement, b) lack of cooperation of the top reinforcement [22] (1-action of bars on the concrete core, 2-action of bars on the cover). 
a)

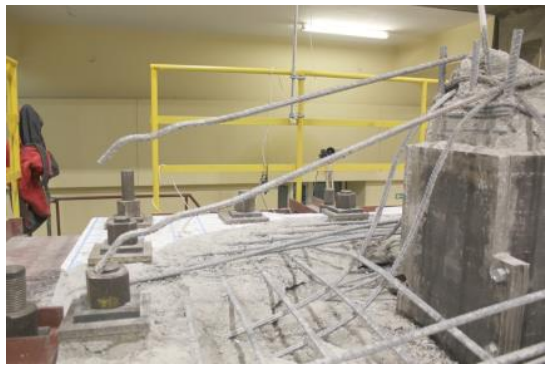

b)

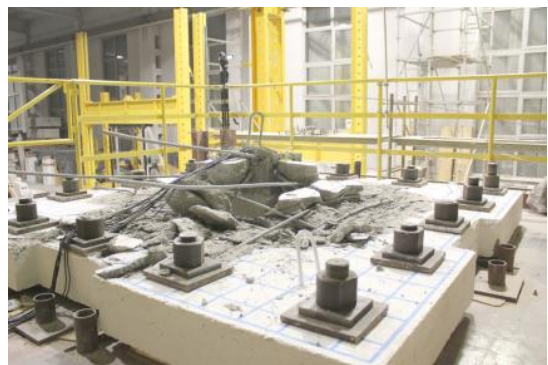

Fig. 7. View of top reinforcement bars - author's own research: a) anchored, b) without anchoring.

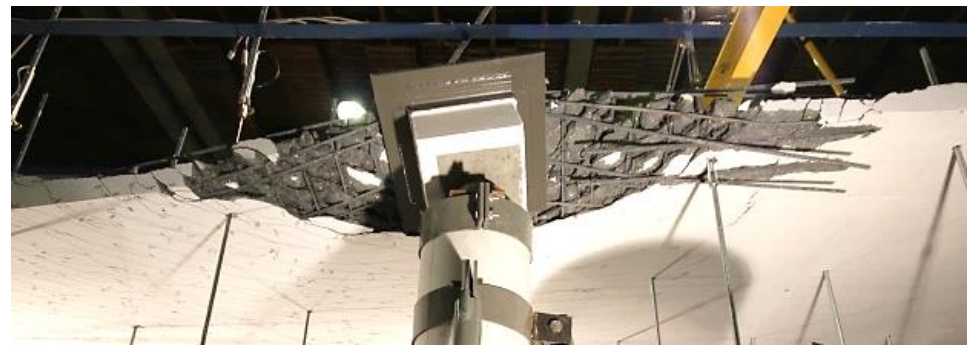

Fig. 8. View of bottom reinforcement bars - research of M.Wieczorek.

Therefore, in an emergency situation only well anchored and continuous integrity reinforcement will be able to hang the damaged slab on columns. Moreover, thanks to this the probability of local punching failure leading to a progressive collapse can be limited. Based on the above, two main tasks for the integrity reinforcement may be defined, namely sustaining the post-punching load-bearing capacity of slab-column connections in the support zone and supporting the span parts at the moment of overloading.

\subsection{Behavior of reinforcement in the span zone}

The possibility of the development of tensile membrane action in various types of concrete slabs in local failures was discussed by Mitchell and Cook [15]. They claimed that "the key in preventing progressive collapse may be to design and detail slabs such that they are able to develop secondary load carrying mechanisms after initial failures have occurred". Besides, they concluded that the tensile membrane action of the slab developed by well anchored reinforcing bars may be used for transferring the damage (Fig. 9). In such a case, the structure will be able to hang the damaged structure elements on columns.

According to the concept, the load shall be transferred by a cover created by reinforcing bars and tensioned in two directions, supported by one-way tendons hanging between columns (Fig. 9). Assuming that one-way tendon will be subject to uniform load of $0.5 q l^{2}$ per unit of length, its load-bearing capacity could be expressed as:

$$
q=\frac{2 T_{\mathrm{c}} \sin \sqrt{6 \varepsilon}}{l_{\mathrm{n}} l_{2}}
$$

where:

$T_{\mathrm{c}}$ - force in the anchored bottom reinforcement in the one-way tendon,

$\varepsilon-$ longitudinal strains of one-way tendon,

$l_{\mathrm{n}}$ - clear span of the one way tendon between columns in the direction considered, 
$l_{2}$ - distance measured from the centerline of the slab on one side of the tendon to the centerline of the slab on the other side of the tendon, measured perpendicularly to the direction considered.

a)

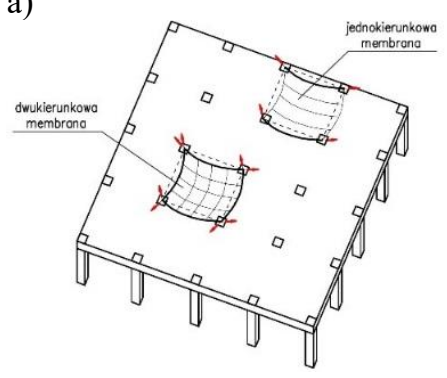

b)

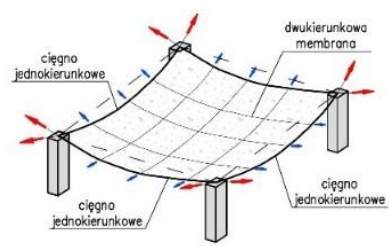

c)

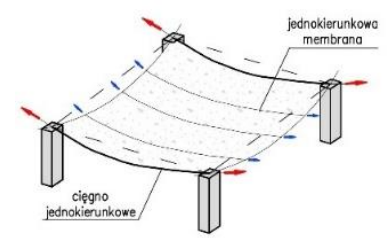

Fig. 9. Development of tensile membrane action in the case of monolithic, bi-directionally flexing plates: a) flat plate construction, b) internal field, c) edge field [15].

\subsection{Behavior of reinforcement in the support zone}

The experimental research [11] [12] has proven that after the slab punching, only in the case of severe deformations of the slab did the bottom reinforcement in the compressed slab zone start to act. The transfer of load to other structural elements of the connection had impact on the redistribution of internal forces. That is why using the integrity reinforcement in the form of a bottom continuous reinforcement passing over the contour of the column is considered crucial for maintaining the proper load-bearing capacity of slab-column connections after punching of the slab [8] [11] [12].

Based on the conducted experimental research, proposals were presented for determining the load-bearing capacity of the connection ensured by integrity reinforcement bars after the slab punching. In 1998, Melo and Regan [12] developed a dependence (2) which was then adapted in the Canadian standard [25].

$$
V_{\mathrm{pp}}=\frac{A_{\mathrm{sb}} f_{\mathrm{yk}}}{2}
$$

The American standard [23] in turn adopts the formula (3) proposed by Mitchell [14] in 1993 which additionally includes the strength reduction factor $\Phi=0.9$.

$$
V_{\mathrm{pp}}=\frac{A_{\mathrm{sb}} \Phi f_{\mathrm{yk}}}{2}
$$

In each case, the post-punching load-bearing capacity of the connection depended on the total area of integrity reinforcement $A_{\text {sb }}$ and the yield strength of steel $f_{\mathrm{yk}}$.

\section{Experimental research}

Many experimental investigations, numerical calculations and theoretical analyses, carried out both abroad and in Poland, were devoted to determining the punching-inducing force in the slab. The results of these investigations led to the development of design instructions included in standards of various countries. However, examples of research that include the descriptions of post-punching behaviour of flat slabs are relatively limited and contain incomplete information. 
As the number of pages is limited, the article only describes the impact of the integrity reinforcement on the increase in the post-punching load-bearing capacity of slab-column connections without providing any details on the geometry of research models and materials used.

\subsection{Review of the research}

The first research directly related to the topic was conducted by Regan [19] in 1979. When investigating two models, the obtained post-punching load-bearing capacity of slab-column connections equalled $73 \%$ of the value of punching force with integrity reinforcement and $21 \%$ in the model without the integrity reinforcement. Based on this, Regan concluded that the presence of integrity reinforcement is of key importance for increasing the load-bearing capacity of the connection after punching.

In 1998, Ghannoum [6 investigated six 3:4 scale models. As part of his research, he determined the post-punching load-bearing capacity, with the post-punching strengthening included in the range between $63 \%$ and $91 \%$ of the punching force in models where integrity reinforcement was used. Moreover, he found out that the post-punching load-bearing capacity was virtually the same in all cases. He justifies the differences between the punching bearing capacity and post-punching bearing capacity with various punching bearing capacities of slabs, highly dependent on concrete strength and ratio of tension reinforcement over the column.

In 2007, the team consisting of Starosolski, Jasiński, Kupczyk, Wieczorek [9] investigated two models of internal slab-column connections different with regard to the grade of the reinforcing steel used. The results have proven that if integrity reinforcement is used when considering high yield steel, the post-punching strengthening equalled $83 \%$ of the punching force, and for medium yield steel the factor amounted to $67 \%$.

In his paper [13], Mirzaei presented and discussed experimental research of three series of models. In the first series, the integrity reinforcement of the models was missing and the investigations were aimed at determining the impact of different degrees of the reinforcement used on the post-punching behavior of the models. In the second series, both straight (properly anchored) bars and bars bent out upwards which passed through the column were used (the bars also functioned as a punching reinforcement). In the third series, the impact of using different types of steel and their parameters was determined. The results have proven that post-punching capacity of slabs without integrity reinforcement was relatively small (about $21 \%-37 \%$ of punching bearing capacity). The reason for it lied in the fact that the upper tensile reinforcement was ripped out of the upper surface of concrete and became ineffective after punching. The post-punching capacities of models with integrity reinforcement were much higher than those of models without this reinforcement, and the value of load-bearing capacity reached as much as $98 \%$ of the punching force. The main conclusion of the investigations was the great impact that the breaking strength of reinforcing steel had on the load-bearing capacity of the connection after punching of the slab.

With the aim of determining the impact of length and distribution of integrity reinforcement on the post-punching behavior of slab-column connections, Redl and Egberts [7] carried out investigations of four models. The range of maximum obtained forces after punching of the slab was $83 \%-95 \%$ of the slab punching bearing capacity.

\subsection{The analysis of the results}

As part of the analysis of the results obtained, the force $V_{\mathrm{pp}}$ accompanying the total failure of the models after punching and the value of force $V_{\mathrm{p}}$ accompanying the punching were compared. Based on this, the ratio of forces $V_{\mathrm{pp}} / V_{\mathrm{p}}$ was determined to be within the range 
of $55 \%-98 \%$ (Fig. 10a). The value of ratio of the load-bearing capacity of models directly following the slab punching $V_{\mathrm{p}}$ ' to the value of punching force $V_{\mathrm{p}}$ were considerably lower, i.e. from $31 \%$ to $69 \%$ (Fig. $10 \mathrm{~b}$ ).

a)

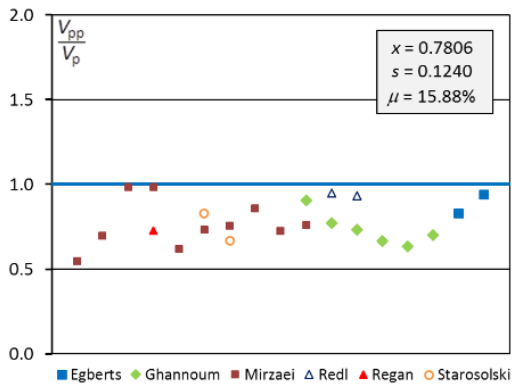

b)

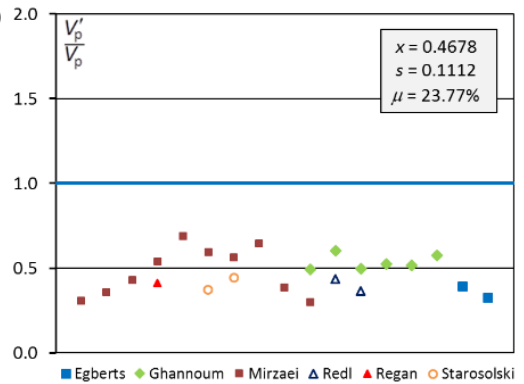

Fig. 10. Comparison of the load-bearing capacity after punching: a) with the value of the punching force, $b$ ) with the force value obtained just after punching.

As can be noticed, none of the investigations carried out allowed to obtain the value of force $V_{\mathrm{pp}}$ leading to the failure of slab-column connection after punching higher than the punching force $V_{\mathrm{p}}$. The average ratio of the forces $V_{\mathrm{pp}} / V_{\mathrm{p}}$ obtained was 0.78 . Moreover, it has been determined that the minimum load-bearing capacity of the connection $V_{\mathrm{p}}$ ' immediately after punching in models with integrity reinforcement has reached the value of only $30 \%$ of punching force $V_{\mathrm{p}}$. Based on 23 results of various studies, the value of force $V_{\mathrm{p}}$ ' was about $47 \%$ of the punching force $V_{\mathrm{p}}$ on average. This allows to infer that the remaining shearing capacity of the slab (i.e. 53\%) should be transferred by integrity reinforcement.

\section{Summary}

Considering the reference works, it can be stated that the phenomenon of progressive collapse in slab-column structures is mostly initiated by brittle failure in the support zone. The examples of collapses in [21] have proven that in the majority of cases, local damage within the range of one of the columns led to the further cascading failure in the remaining part of the structure. That is why safeguarding of this zone is extremely important considering the possibility of further structure failure beyond the support zone and due to financial and moral reasons. The use of integrity reinforcement is one of the options of safeguarding the structure against progressive collapse. Its simplicity makes it also the most economical solution. Unfortunately, the importance of the topic is modestly reflected in experimental research or numerical analyses carried out. Also applicable regulations included in standards (e.g. in Eurocodes) describe the problem to a limited extent only and provide the methodology for proper designing of reinforcement in the support zone.

\section{References}

[1] Afhami S., Alexander S.D.B., Simmonds S.H.: Strip model for capacity of slab-column connection, Structural Engineering Report No. 223, University of Alberta (1998)

[2] Dragosavic M., Van den Beukel A.: Punching shear, Heron, 20, 2 (1974)

[3] Ellingwood B.: Mitigating risk from abnormal loads and progressive collapse, Journal of Performance of Constructed Facilities, 20, 4 (2006) 
[4] Ellingwood B., Leyendecker E.V.: Approaches for design against progressive collapse, Journal of the Structural Division, Proceedings of the American Society of Civil Engineers, 104 (1978)

[5] Ellingwood B., Smilowitz R., Dusenberry D., Duthinh D., Lew H.S., Carino N.J.: Best practices for reducing the ptential for progressive collapse in buildings, National Institute of Standard and Technology, NISTIR 7396 (2007)

[6] Ghannoum, C.M.: Effect of high-strength concrete on the performance of slab-column specimens, Department of Civil Engineering, McGill University, Montreal, QC (1998)

[7] Habibi F., Redl E., Egberts M., Cook W.D., Mitchell D.: Assessment of CSA A23.3 structural integrity requirements for two-way slabs, Canadian Journal of Civil Engineering, 39, 4 (2012)

[8] Hawkins N.M., Mitchell D.: Progressive collapse of flat plate structures, ACI Journal, 76, 10 (1979)

[9] Jasiński R., Kupczyk R., Starosolski W, Wieczorek M.: Badania żelbetowych połączeń płyta-słup w stadium awaryjnym, Inżynieria i Budownictwo, nr 11 (2009)

[10] Jelić I., Pavlović M.N., Kotsvos M.D.: A study of dowel action in reinforced concrete beams, Magazine of Concrete Research, 51, 2 (1999)

[11] Kupfer H., Georgopoulos T.: Eine kostengünstige Massnahme zur Vermeidung des fortschreitenden Einsturzes punktgestützter Stahlbetonplatten infolge Durchstanzens, Bauingenieur, Heft 61 (1986)

[12] Melo G.S., Regan P.E.: Post-punching resistance of connections between flat slabs and interior columns, Magazine of Concrete Research, 50, 4 (1998)

[13] Mirzaei Y., Muttoni A.: Tests of the post-punching behavior of the reinforced concrete flat slabs, IS-BETON, Switzerland (2008)

[14] Mitchell D.: Controversial issues in the seismic design of reinforced concrete frames, Recent Developments in Lateral Force Transfer in Buildings, Thomas Paulay Symposium, American Concrete Institute, La Jolla, CA (1993)

[15] Mitchell D., Cook W.D.: Preventing progressive collapse of slab structures, Journal of Structural Engineering, 110, 7 (1984)

[16]Park R.: Tensile membrane behaviour of uniformly loaded rectangular reinforced concrete slabs with fully restrained edges, Magazine of Concrete Research, 16, 40 (1964)

[17] Polak M.A.: Ductility of reinforced concrete flat slab-column connections, ComputerAided Civil and Infrastructure Engineering, 20 (2005)

[18] Rankin G.I.B., Long A.E.: Predicting the punching strength of conventional slab-column specimens, Proceedings of the Institution of Civil Engineers, Part 1 Design and Construction, 82 (1987)

[19] Regan P.E., Walker P.R., Zakaria K.A.A.: Tests of reinforced concrete flat slabs, School of the Environment, Polytechnic of Central, CIRIA Project RP 220, London, UK, (1979)

[20] Starosolski W: Zabezpieczenie ustrojów przed obciążeniami wyjątkowymi, XXV Ogólnopolskie Warsztaty Pracy Projektanta Konstrukcji (Nowoczesne rozwiązania konstrukcyjno - materiałowo - technologiczne. Konstrukcje żelbetowe.), Szczyrk, 10-13 marca 2010 r. T. 3: Wykłady, Polski Związek Inżynierów i Techników Budownictwa o/Gliwicach, AMGRAF, Gliwice (2010)

[21] Starosolski W., Wieczorek B., Wieczorek M.: Konstrukcje płytowo-słupowe. Zabezpieczenia przeciwko katastrofie postępującej, Biuletyn techniczny nr 6, Centrum Promocji Jakości Stali, Warszawa (2015)

[22] Urban T.S.: Przebicie w żelbecie, Wybrane zagadnienia, Łódź (2005) 
[23] ACI 352.1R-89: Recommendations for design of slab-column connections in monolithic reinforced concrete structures, American Concrete Institute, ACI-ASCE Committee 352, USA (1988)

[24] Construction en béton, Introduction à la norme SIA 262, Extrait de la documentation D 0182, Société suisse des ingénieurs et des architectes, Zürich, Switzerland (2003)

[25]CSA Standard A23.3-04, Canadian Standard Association (2004) 